\title{
Clinical Data, Laboratory Investigations and Electrocardiographic Changes as Predictors of Mortality in Acute Aluminum Phosphide Poisoning
}

\author{
Amira A. Wahdan ${ }^{* *}$ and Heba K. Khalifa ${ }^{1}$
}

\begin{abstract}
KEYWORDS

Aluminum phosphide, Clinical, Investigations,

Electrocardiographic changes, Mortality,

Prediction

Aluminum phosphide (AIP) is a fumigant widely used in Egypt. Limited data is available about mortality prediction in AIP poisoned patients. This work was designed to evaluate role of clinical data, laboratory investigations and ECG findings in predicting mortality in these cases. A cohort retrospective study was conducted on 113 cases of AIP poisoning admitted to Tanta University Poison Control Center. History, clinical data and results of laboratory investigations were recruited. The mortality rate was $68.1 \%$. There was a significant difference between survivors and non- survivors as regards mode of poisoning, GCS, vital signs (except heart rate), ECG abnormalities, pH, $\mathrm{HCo3}, \mathrm{K}$, creatine level and white blood cell count. The multivariate analysis logistic regression revealed that ECG changes and pH level were the only independent variables that can predict mortality. Analysis of receiver operating curve of blood pH level revealed a good area under the curve (AUC) of 0.881 . At a cut off value of $\leq 7.28$ the blood $\mathrm{pH}$ level had a sensitivity of 71.43 . It was concluded that AIP poisoning causes high mortality rate. Mortality could be predicted by ECG changes and blood pH level. At a cut off value of $\leq 7.28$ the blood $\mathrm{pH}$ level was able to predict mortality. ECG assessment and blood pH monitoring are highly recommended in cases of AIP poisoning for early prediction of mortality.
\end{abstract}

\section{Introduction}

Pesticides poisoning is one of the major public health problems. According to International Programme on Chemical Safety, consumption of pesticides results in 370000 deaths per year. Many of these deaths result from Aluminum phosphide (AlP) Poisoning (Prashar and Ramesh, 2018). In Egypt, it is widely used as a grain preservative because of its low cost and easy availability. Moreover, it is highly potent against broad spectrum of insect species, not affecting seed viability and

\footnotetext{
${ }^{(1)}$ Forensic Medicine and Clinical Toxicology Department, Faculty of Medicine, Tanta University, Egypt.

* Corresponding author:

E-mail: amira.wahdan@med.tanta.edu.eg dr.awahdan@yahoo.com
}

leaves little residues on food grains (Mostafazadeh et al., 2011; Nagy et al., 2015).

When AlP comes in contact with water, moisture in the air, or hydrochloric acid in the stomach, it liberates toxic phosphine gas (PH3), which is rapidly absorbed by inhalation, ingestion and dermal contact (Navabi et al., 2018). The exact mechanism of action of AlP is still unknown; however, several mechanisms have been described for phosphides toxicity. Cellular damage and cardio-respiratory failure are the most common mechanisms of mortality and morbidity induced by AlP poisoning (Proudfoot, 2009; Hassanian - Moghaddam et al., 2016).

According to Bumbrah et al. (2012), cytotoxic phosphine gas generated due to acid 
hydrolysis of AlP affects heart, lungs, kidneys and gastrointestinal tract. AlP toxicity causes nausea, restlessness, abdominal pain, palpitation, pulmonary edema, cyanosis, hypotension, shock and cardiac arrhythmias. Other rare effects include hepatitis, acute tubular necrosis, disseminated intravascular coagulation and respiratory alkalosis. These detrimental effects have been described by several authors over a long period of time.

Predicting outcome and mortality in critically ill patients is a key component and a major concern of any health care system. Detrimental effects of AlP poisoning are a big problem with major consequences. In the same time, there is a striking lack of recent studies regarding predictors of mortality in acute AlP toxicity (Mathai and Bhanu, 2010; Khan, 2015).

Hereafter, the current study aimed to use clinical data, laboratory investigations and ECG findings in acute AlP intoxication as simple tools for prediction of mortality.

\section{Subjects and methods:}

Study design: This is a cohort retrospective study which was carried out in Tanta University Poison Control Center (TUPCC) after being approved by the research ethical committee of Tanta Faculty of Medicine (approval code: 33156/05/19).

Subjects: This study included data of 113 cases suffering from acute AlP poisoning in a 2 years period from the start of October 2016 to the end of September 2018. The data were recruited from the hospital records after approval from the head of TUPCC.

\section{Inclusion criteria:}

Cases (from both genders and all ages) who are suffering from acute AlP poisoning are included.

\section{Exclusion criteria:}

1- Cases with ingestion or exposure to other substances in addition to AlP.

2- Cases with other major medical conditions (e.g. cardiovascular disease, renal or hepatic failure).

3- Cases treated for acute AlP poisoning in any medical center before admission to TUPCC.

4- Cases with incomplete hospital records.

Data confidentiality was maintained by making code numbers (available to investigators only) for each patient. All the data were analyzed anonymously.

For each case, the following data were collected:

a) History:

1- Personal history with emphasis on age, gender and residence.

2- Toxicological history including; mode of poisoning, route of exposure and delay time.

b) Clinical data:

1- Vital signs (pulse, blood pressure, temperature and respiratory rate).

2- Level of consciousness by Glasgow Coma Scale (GCS).

3- Electrocardiographic (ECG) monitoring.

c) Results of laboratory investigations: (on admission)

Including results for:

- Arterial blood gases (ABG) with emphasis on $\mathrm{pH}$ and bicarbonate level.

- Serum sodium and potassium.

- Liver enzymes: serum aspartate transaminase (AST) and alanine transaminase (ALT) activities.

- Kidney function tests: blood urea and serum creatinine. 
- Complete blood count (CBC) with emphasis on white blood cell count.

- Random blood sugar (RBS)

\section{Statistical analysis:}

Data were fed to the computer and analyzed using IBM SPSS software package version 20.0 (Armonk, NY: IBM Corp). The Kolmogorov- Smirnov, Shapiro and D'agstino tests were used to verify the normality of distribution of variables. Comparisons between groups for categorical variables were assessed using Chi-square test (Fisher or Monte Carlo). Student t-test was used to compare two groups for normally distributed quantitative variables while Mann Whitney test was used to compare between two groups for abnormally distributed quantitative variables. Univariate analysis and multivariate analysis logistic regression were done to identify the variables that can predict mortality. Receiver-operating characteristic
(ROC) curves for predicting the probability of mortality were generated from the data. Area under ROC curve, sensitivity, specificity, positive predictive values (PPV) and negative predictive values (NPV) were calculated. The area under ROC curve (AUC) is graded as follows: $0.90-1=$ excellent; $0.80-0.90=$ good; $0.70-0.80=$ fair and $0.60-0.70=$ poor. Significance was adopted at $p<0.05$ for interpretation of results of tests (Dawson and Trapp, 2001).

\section{Results:}

During the study period, 113 cases have fulfilled the inclusion criteria. Their sociodemographic data (age, gender and residence) and toxicological data (mood of poisoning, route of exposure and delay time between exposure and arrival to hospital) are presented in table (1).

Table (1): Distribution of sociodemographic and toxicological data of cases of aluminum phosphide poisoning included in the study (113 cases).

\begin{tabular}{|c|c|c|c|}
\hline \multirow{2}{*}{ Age (years) } & \multicolumn{2}{|c|}{ Min- Max. } & \multirow{2}{*}{$\frac{11-50}{20}$} \\
\hline & & & \\
\hline \multirow{4}{*}{ Gender } & \multirow{2}{*}{ Female } & $\mathrm{n}$ & 70 \\
\hline & & $\%$ & 61.9 \\
\hline & \multirow{2}{*}{ Male } & $\mathrm{n}$ & 43 \\
\hline & & $\%$ & 38.1 \\
\hline \multirow{4}{*}{ Residence } & \multirow{2}{*}{ Urban } & $\mathrm{n}$ & 16 \\
\hline & & $\%$ & 14.2 \\
\hline & \multirow{2}{*}{ Rural } & $\mathrm{n}$ & 97 \\
\hline & & $\%$ & 85.8 \\
\hline \multirow{4}{*}{ Mode of poisoning } & \multirow{2}{*}{ Accidental } & $\mathrm{n}$ & 11 \\
\hline & & $\%$ & 9.7 \\
\hline & \multirow{2}{*}{ Suicidal } & $\mathrm{n}$ & 102 \\
\hline & & $\%$ & 90.3 \\
\hline \multirow{4}{*}{ Route of exposure } & \multirow{2}{*}{ Ingestion } & $\mathrm{n}$ & 109 \\
\hline & & $\%$ & 96.5 \\
\hline & \multirow{2}{*}{ Inhalation } & $\mathrm{n}$ & 4 \\
\hline & & $\%$ & 3.5 \\
\hline \multirow{2}{*}{ Delay (Hours) } & \multicolumn{2}{|l|}{ Range } & $0.5-14$ \\
\hline & \multicolumn{2}{|l|}{ Median } & 2 \\
\hline
\end{tabular}

n: number, Min.- Max.: minimum- maximum. 
Table (2) shows that 77 cases died with an overall mortality rate of $68.1 \%$ (this represented the non-survivor group). There was no statistically significant difference between survivors and non- survivors as regards age, gender, residence, route of exposure and delay time. On the other hand, a statistically significant difference between the two groups as regards mode of exposure was detected.

Table (2): Comparison between survivor and non-survivor groups following aluminum phosphide poisoning regarding sociodemographic and toxicological data (number $=113$ ).

\begin{tabular}{|c|c|c|c|c|}
\hline \multirow{4}{*}{\begin{tabular}{|l} 
Age (years) \\
\end{tabular}} & \multicolumn{2}{|c|}{ Outcome } & \multirow[b]{2}{*}{ Test of Sig. } & \multirow[b]{2}{*}{ p value } \\
\hline & \multirow[t]{2}{*}{$\begin{array}{c}\text { Survivors } \\
(\mathrm{n}=\mathbf{3 6})\end{array}$} & $\begin{array}{c}\text { Non survivors } \\
(\mathbf{n}=77)\end{array}$ & & \\
\hline & & & & \\
\hline & $15-50$ & $11-50$ & \multirow{2}{*}{$\begin{array}{c}U= \\
1238.50\end{array}$} & \multirow{2}{*}{0.362} \\
\hline Median & 21 & 20 & & \\
\hline \multicolumn{5}{|l|}{$\overline{\operatorname{Sex}}$} \\
\hline Male & $13(36.1 \%)$ & $30(39 \%)$ & \multirow{2}{*}{$\begin{array}{c}\chi^{2}= \\
0.085\end{array}$} & \multirow{2}{*}{0.771} \\
\hline Female & $23(63.9 \%)$ & $47(61 \%)$ & & \\
\hline \multicolumn{5}{|l|}{ Residence } \\
\hline Rural & $28(77.8 \%)$ & $69(89.6 \%)$ & \multirow{2}{*}{$\begin{array}{c}\chi^{2}= \\
2.826\end{array}$} & \multirow{2}{*}{0.093} \\
\hline Urban & $8(22.2 \%)$ & $8(10.4 \%)$ & & \\
\hline \multicolumn{5}{|c|}{ Mode of poisoning } \\
\hline Accidental & $9(25 \%)$ & $2(2.6 \%)$ & \multirow{2}{*}{$\begin{array}{c}\chi^{2}= \\
14.011^{*}\end{array}$} & \multirow{2}{*}{$0.001^{*}$} \\
\hline Suicidal & $27(75 \%)$ & $75(97.4 \%)$ & & \\
\hline \multicolumn{5}{|c|}{ Route of exposure } \\
\hline Ingestion & $33(91.7 \%)$ & $76(98.7 \%)$ & \multirow{2}{*}{$\begin{array}{c}\chi^{2}= \\
3.555\end{array}$} & \multirow{2}{*}{0.095} \\
\hline Inhalation & $3(8.3 \%)$ & $1(1.3 \%)$ & & \\
\hline \multicolumn{5}{|c|}{ Delay time (hours) } \\
\hline Min. -Max. & $0.5-14$ & $0.5-14$ & \multirow{2}{*}{$\begin{array}{c}U= \\
1083.50\end{array}$} & \multirow{2}{*}{0.161} \\
\hline Median & 3 & 2 & & \\
\hline
\end{tabular}

$\chi^{2}$ : Chi square test, U: Mann Whitney test, $\mathrm{p}: \mathrm{p}$ value, ${ }^{*}$ : Statistically significant at $\mathrm{p} \leq 0.05$, n: number, Min.- Max.: minimum- maximum.

Table (3) revealed a comparison between survivors and non-survivors considering Glasgow coma scale (GCS), vital signs and the presence of ECG abnormalities. Statistically significant difference could be detected between survivors and non-survivors as regards all these parameters except the heart rate. ECG finding among survivors, non-survivors and the whole study population were recorded in table (4). 
Table (3): Comparison between survivor and non-survivor groups following aluminum phosphide poisoning regarding the clinical data and ECG findings (number $=113$ )

\begin{tabular}{|c|c|c|c|c|c|}
\hline & \multirow[b]{2}{*}{$\begin{array}{c}\text { Total } \\
(n=113)\end{array}$} & \multicolumn{2}{|c|}{ Outcome } & \multirow[b]{2}{*}{ Test of Sig. } & \multirow[b]{2}{*}{$p$ value } \\
\hline & & $\begin{array}{c}\text { Survivors } \\
(\mathrm{n}=\mathbf{3 6})\end{array}$ & $\begin{array}{c}\text { Non survivors } \\
(\mathbf{n}=77)\end{array}$ & & \\
\hline \multicolumn{6}{|l|}{ GCS } \\
\hline Min. -Max. & $3-15$ & $12-15$ & $3-15$ & \multirow{2}{*}{$\mathrm{U}=973.0^{*}$} & \multirow{2}{*}{$0.002^{*}$} \\
\hline Median & 15 & 15 & 15 & & \\
\hline \multicolumn{6}{|l|}{ Pulse (b/min) } \\
\hline Min.-Max. & $40-143$ & $60-134$ & $40-143$ & \multirow{2}{*}{$\mathrm{U}=1237.5$} & \multirow{2}{*}{0.547} \\
\hline Median & 98 & 90 & 99 & & \\
\hline \multicolumn{6}{|c|}{ Respiratory rate (cycle/min) } \\
\hline Min. -Max. & $16-55$ & $16-27$ & $17-55$ & \multirow{2}{*}{$\mathrm{U}=859.0^{*}$} & \multirow{2}{*}{$0.001^{*}$} \\
\hline Median & 22 & 21 & 23.5 & & \\
\hline \multicolumn{6}{|c|}{ Systolic blood pressure (mmHg) } \\
\hline Min. -Max. & $40-160$ & $60-160$ & $40-130$ & \multirow{2}{*}{$\mathrm{t}=5.439^{*}$} & \multirow{2}{*}{$<0.001^{*}$} \\
\hline Mean \pm SD. & $89.7 \pm 23.7$ & $105.7 \pm 25$ & $79.8 \pm 16.5$ & & \\
\hline \multicolumn{6}{|c|}{ Diastolic blood pressure (mmHg) } \\
\hline Min. -Max. & $30-100$ & $30-100$ & $30-80$ & \multirow{2}{*}{$\mathrm{t}=5.303^{*}$} & \multirow{2}{*}{$<0.001^{*}$} \\
\hline Mean \pm SD. & $55.4 \pm 16.9$ & $66.6 \pm 17.8$ & $48.5 \pm 12$ & & \\
\hline \multicolumn{6}{|l|}{ Blood pressure } \\
\hline Normal (\%) & $36(31.9 \%)$ & $23(63.9 \%)$ & $13(16.9 \%)$ & \multirow{2}{*}{$\chi^{2}=24.968^{*}$} & \multirow{2}{*}{$<0.001^{*}$} \\
\hline Abnormal (\%) & $77(68.1 \%)$ & $13(36.1 \%)$ & $64(83.1 \%)$ & & \\
\hline \multicolumn{6}{|l|}{ ECG } \\
\hline Normal (\%) & $20(17.7 \%)$ & $12(33.3 \%)$ & $8(10.4 \%)$ & \multirow{2}{*}{$\chi^{2}=8.865$} & \multirow{2}{*}{$0.003 *$} \\
\hline Abnormal (\%) & $93(82.3 \%)$ & $24(66.7 \%)$ & $69(89.6 \%)$ & & \\
\hline
\end{tabular}

$\chi^{2}$ : Chi square test, U: Mann Whitney test, $t:$ student $t$ test, $p: p$ value, ${ }^{*}$ : Statistically significant at $p \leq 0.05$, n: number, Min.- Max.: minimum- maximum.

Table (4): ECG findings among survivors, non-survivors and the whole study population following aluminum phosphide poisoning (number $=113$ )

\begin{tabular}{|c|c|c|c|c|}
\hline \multirow{2}{*}{\multicolumn{2}{|c|}{ ECG finding }} & \multirow{2}{*}{$\begin{array}{c}\text { Total } \\
(\mathrm{n}=113)\end{array}$} & \multicolumn{2}{|c|}{ Outcome } \\
\hline & & & $\begin{array}{c}\text { Survivors } \\
(\mathrm{n}=\mathbf{3 6})\end{array}$ & $\begin{array}{c}\text { Non-survivors } \\
(\mathbf{n}=77)\end{array}$ \\
\hline \multicolumn{2}{|c|}{ Normal ECG } & $20(17.7 \%)$ & $12(33.3 \%)$ & $8(10.4 \%)$ \\
\hline \multirow{8}{*}{$\begin{array}{l}\text { ECG } \\
\text { changes }\end{array}$} & Sinus tachycardia & $45(39.8 \%)$ & $16(44.4 \%)$ & $29(37.7 \%)$ \\
\hline & Ventricular fibrillation & $4(3.5 \%)$ & $0(0 \%)$ & $4(5.2 \%)$ \\
\hline & Atrial fibrillation & $13(11.5 \%)$ & $3(8.3 \%)$ & $10(13 \%)$ \\
\hline & Sinus bradycardia & $13(11.5 \%)$ & $2(5.6 \%)$ & $11(14.3 \%)$ \\
\hline & Ventricular tachycardia & $4(3.5 \%)$ & $0(0 \%)$ & $4(5.2 \%)$ \\
\hline & Extrasystole & $6(5.3 \%)$ & $1(2.8 \%)$ & $5(6.5 \%)$ \\
\hline & Inverted T-wave & $4(3.5 \%)$ & $1(2.8 \%)$ & $3(3.9 \%)$ \\
\hline & S-T elevation & $4(3.5 \%)$ & $1(2.8 \%)$ & $3(3.9 \%)$ \\
\hline
\end{tabular}

ECG: electrocardiogram. 
Comparison between survivors and non-survivors considering results of $\mathrm{ABG}$ analysis, electrolyte level, liver enzymes, kidney function tests, RBS level and white blood cell count detected a significant statistical difference in $\mathrm{pH}, \mathrm{HCO}_{3}, \mathrm{~K}$ and creatine level and white blood cell count (Table $5)$.

Table (5): Comparison between survivor and non-survivor groups following aluminum phosphide poisoning regarding results of laboratory investigations (number $=113$ )

\begin{tabular}{|c|c|c|c|c|c|}
\hline & \multirow[b]{2}{*}{$\begin{array}{c}\text { Total } \\
(n=113)\end{array}$} & \multicolumn{2}{|r|}{ Outcome } & \multirow[b]{2}{*}{ Test of Sig. } & \multirow[b]{2}{*}{$\mathbf{p}$} \\
\hline & & $\begin{array}{l}\text { Survivors } \\
(\mathrm{n}=36)\end{array}$ & $\begin{array}{c}\text { Non survivors }(\mathrm{n}= \\
77)\end{array}$ & & \\
\hline \multicolumn{6}{|c|}{ 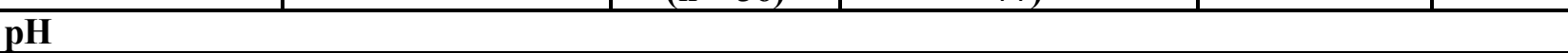 } \\
\hline Min.- Max. & $7.1-7.5$ & $7.2-7.5$ & $7.1-7.5$ & \multirow{2}{*}{$\mathrm{t}=9.472^{*}$} & \multirow{2}{*}{$<0.001^{*}$} \\
\hline Mean \pm SD. & $7.3 \pm 0.1$ & $7.4 \pm 0.1$ & $7.2 \pm 0.1$ & & \\
\hline \multicolumn{6}{|l|}{$\mathrm{HCo}_{3}(\mathrm{mEq} / \mathrm{L})$} \\
\hline Min.- Max. & $5.3-33$ & $10-33$ & $5.3-33$ & \multirow{2}{*}{$\mathrm{U}=449.5^{*}$} & \multirow{2}{*}{$<0.001^{*}$} \\
\hline Median & 15.3 & 19.5 & 11.8 & & \\
\hline \multicolumn{6}{|l|}{ ALT (U/L) } \\
\hline Min.- Max. & $2-85$ & $5-44$ & $2-85$ & \multirow{2}{*}{$\mathrm{U}=1204.0$} & \multirow{2}{*}{0.261} \\
\hline Median & 20 & 18.5 & 21 & & \\
\hline \multicolumn{6}{|l|}{$\operatorname{AST}(\mathrm{U} / \mathrm{L})$} \\
\hline Min.- Max. & $6-90$ & $10-40$ & $6-90$ & \multirow{2}{*}{$\mathrm{U}=1244.5$} & \multirow{2}{*}{0.383} \\
\hline Median & 21 & 21.5 & 21 & & \\
\hline \multicolumn{6}{|l|}{ Urea (mg\%) } \\
\hline Min.- Max. & $15-53$ & $15-53$ & $15-48$ & \multirow{2}{*}{$\mathrm{U}=1209.0$} & \multirow{2}{*}{0.275} \\
\hline Median & 28 & 30 & 27 & & \\
\hline \multicolumn{6}{|c|}{ Creatine (mg\%) } \\
\hline Min.- Max. & $0.5-2.4$ & $0.5-1.4$ & $0.5-2.4$ & \multirow{2}{*}{$\mathrm{U}=911.0^{*}$} & \multirow{2}{*}{$0.004^{*}$} \\
\hline Median & 1 & 0.8 & 1 & & \\
\hline \multicolumn{6}{|l|}{$\mathrm{Na}(\mathrm{mg} \%)$} \\
\hline Min.- Max. & $130.6-155$ & $132.5-152$ & $130.6-155$ & \multirow{2}{*}{$\mathrm{t}=0.493$} & \multirow{2}{*}{0.623} \\
\hline Mean \pm SD. & $140.4 \pm 4.8$ & $140.1 \pm 4.5$ & $140.6 \pm 5$ & & \\
\hline \multicolumn{6}{|l|}{ K (mg\%) } \\
\hline Min.- Max. & $2.2-5.4$ & $2.6-5.3$ & $2.2-5.4$ & \multirow{2}{*}{$\mathrm{t}=2.855^{*}$} & \multirow{2}{*}{$0.005^{*}$} \\
\hline Mean \pm SD. & $3.5 \pm 0.7$ & $3.8 \pm 0.7$ & $3.4 \pm 0.6$ & & \\
\hline \multicolumn{6}{|c|}{ Random blood Sugar (mg\%) } \\
\hline Min.- Max. & $42-413$ & $79-410$ & $42-413$ & \multirow{2}{*}{$\mathrm{U}=1151.5$} & 0148 \\
\hline Median & 130 & 120 & 137 & & 0.148 \\
\hline WBCs $\left(\times 10^{3}\right)$ & & & & & \\
\hline Min.- Max. & $2.7-18.7$ & $2.7-18.7$ & $5-16.6$ & $\mathrm{U}=10130^{*}$ & $0021^{*}$ \\
\hline Median & 11.7 & 8.7 & 11.8 & & \\
\hline
\end{tabular}

U: Mann Whitney test, $t$ : student $t$ test, $p: p$ value, *: Statistically significant at $p \leq 0.05$, n: number, Min.- Max.: minimum- maximum.

Univariate analysis detected a statistically significant relationship between mortality and all the following; the presence of ECG changes, GCS, blood pressure disorders, respiratory rate, $\mathrm{pH}, \mathrm{HCo}_{3}, \mathrm{~K}$ and creatine level and white blood cell count. While the multivariate analysis logistic regression revealed that the presence of ECG changes and the $\mathrm{pH}$ level are the only independent variables that can predict mortality (Table 6). 
Table (6): Univariate analysis and multivariate analysis logistic regression differentiation between survivors and non-survivors following aluminum phosphide poisoning (number $=113$ ).

\begin{tabular}{|l|c|c|c|c|}
\hline \multirow{2}{*}{ ECG changes } & \multicolumn{2}{|c|}{ Univariate } & \multicolumn{2}{c|}{ Multivariate } \\
\cline { 2 - 5 } & $\mathbf{p}$ & OR (95\% C.I) & $\mathbf{p}$ & OR (95\% C.I) \\
\hline GCS & $0.004^{*}$ & $4.312(1.574-11.817)$ & $0.048^{*}$ & $7.291(1.017-52.262)$ \\
\hline Blood pressure disorders & $<0.001^{*}$ & $8.710(3.526-21.519)$ & 0.126 & $3.129(0.725-13.505)$ \\
\hline Respiratory rate & $0.002^{*}$ & $1.180(1.065-1.307)$ & 0.063 & $1.249(0.988-1.578)$ \\
\hline PH & $<0.001^{*}$ & $0.183(0.098-0.341)$ & $<0.001^{*}$ & $0.141(0.049-0.404)$ \\
\hline Hco3 & $<0.001^{*}$ & $0.781(0.707-0.863)$ & 0.810 & $0.979(0.822-1.166)$ \\
\hline Creatine & $0.007^{*}$ & $9.049(1.827-44.828)$ & 0.323 & $4.780(0.214-106.535)$ \\
\hline K & $0.007^{*}$ & $0.426(0.228-0.796)$ & 0.147 & $0.429(0.137-1.345)$ \\
\hline WBCs $\left(\times \mathbf{1 0}^{\mathbf{3}}\right)$ & $0.014^{*}$ & $1.168(1.032-1.322)$ & 0.598 & $1.056(0.863-1.291)$ \\
\hline
\end{tabular}

OR: Odd's ratio, C.I: Confidence interval, \#: All variables with $\mathrm{p}<0.05$ were included in the multivariate regression, *: Statistically significant at $\mathrm{p} \leq 0.05$.

Table (7) and figure (1) show the results of analysis of ROC curve of blood $\mathrm{pH}$ level as a predictor of mortality. Blood $\mathrm{pH}$ level has an AUC of 0.881 which is graded as good AUC. The optimal cut-off value of blood $\mathrm{pH}$ was identified. At a cut off values of $\leq 7.28$ the blood $\mathrm{pH}$ level had a sensitivity of 71.43 and a specificity of 97.22. Moreover, PPV (the probability that a patient at a certain cut off value will die) have been calculated and was $98.2 \%$

Table (7): Receiver operating characteristic (ROC) curve for blood $\mathrm{pH}$ level for prediction of mortality following aluminum phosphide poisoning (number $=113$ ).

\begin{tabular}{|c|c|c|c|c|c|c|c|c|}
\hline & $\underset{2}{U}$ & $A$ & $\begin{array}{l}\vec{u} \\
\text { in } \\
\text { ò }\end{array}$ & 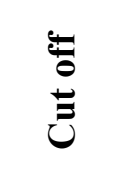 & 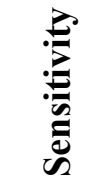 & 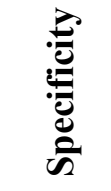 & $\vec{a}$ & $\frac{2}{z}$ \\
\hline $\mathbf{p H}$ & 0.881 & $<0.001^{*}$ & $0.817-0.945$ & $\leq 7.28$ & 71.43 & 97.22 & 98.2 & 61.4 \\
\hline
\end{tabular}

AUC: Area under a Curve, $p$ value: Probability value, CI: Confidence Intervals, PPV: Positive predictive value, NPV: Negative predictive value, $*$ : Statistically significant at $p \leq 0.05$. 


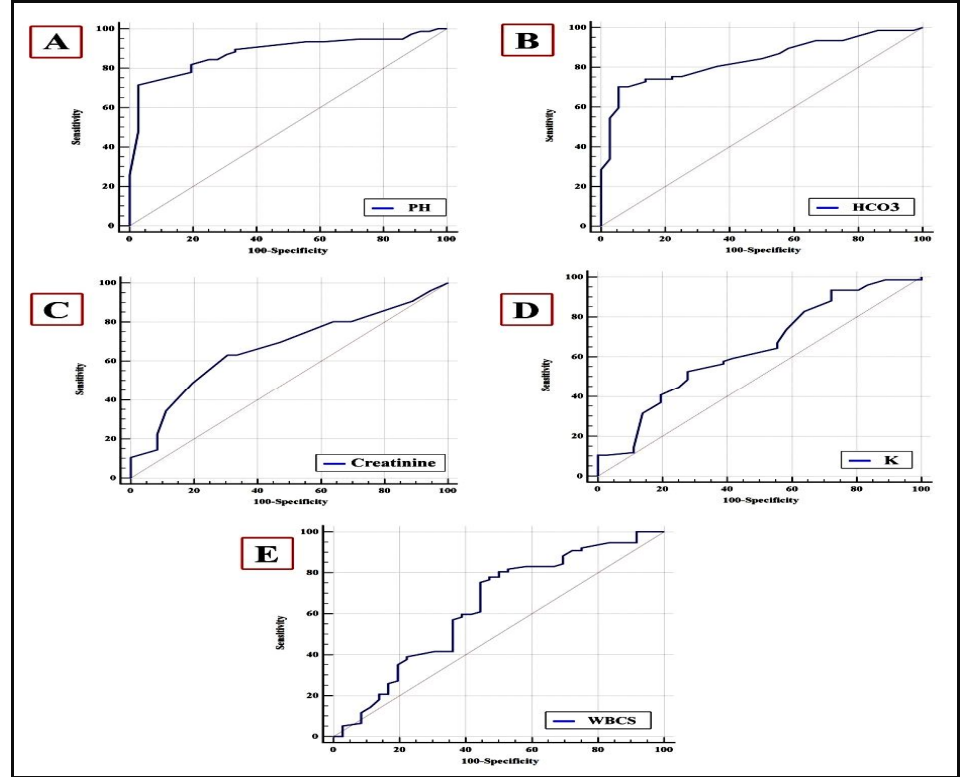

Fig. (1): Receiver operating characteristic (ROC) curve for blood $\mathrm{pH}$ level for prediction of mortality following aluminum phosphide poisoning.

\section{Discussion}

Aluminum phosphide is a potent pesticide. It is used for crops protection during storage and transportation (Bumbrah et al., 2012). Acute AlP toxicity is associated with high risk of morbidity and mortality (Singh et al., 2014). Therefore, the current study was designed to evaluate role of clinical data, laboratory investigations and ECG changes in mortality prediction in acute AlP poisoning.

Sociodemographic characteristics, and toxicological data in this study were comparable to results gathered from different poison control centers in Egypt and across the developing world (El Naggar and El Mahdy, 2011; Hosseinian et al., 2011; Vijayanath et al., 2011; Soltaninejad et al., 2012).

The mortality rate in this study was about $68 \%$. This rate is near to rates reported by Masoud and Barghash (2013) and El-Ebiary et al. (2015) from Egypt (64\% and 67.5\% respectively). This high mortality rate might be due to the easy availability and cheap price of AlP and the absence of specific antidote (Sulaj et al., 2015).
Glasgow coma scale registered significant difference between survivors and non-survivors in the current study. In the same line of this result, Louriz et al. (2009) and El-Ebiary et al. (2015) reported significantly lower values of GCS in non survivors when compared to survivors. Disturbed consciousness level induced by AlP poisoning may be due to cerebral anoxia resulting from refractory shock (Mehrpour et al., 2012). Such phosphides induced neural injury was previously mentioned by Guale et al. (1994). They described central nervous system intoxication as clinical sign in phosphides poisoning. In post-mortem reports; Tripathi and Pandey (2007) reported distinct changes in the cerebral and cerebellar cortex due to the effect of phosphides on human brain.

Systolic and diastolic blood pressure recorded significant lower mean values for non-survivors when compared to survivors. Furthermore, a significantly higher percentage of non- survivors showed abnormal blood pressure. These results were similar to results 
reported by El-Ebiary et al. (2015) and ElSarnagawy (2017). Aluminum phosphide induced hypotension is due to direct myocardial depressive effect, adrenal insufficiency with inadequate systemic vasoconstriction, massive intravascular fluid loss as a result of increased permeability of capillaries and decreasing left ventricular ejection fraction (Marashi et al., 2011; Farnaghi et al., 2013). Moreover, hypovolemia due to vomiting could contribute to hypotension (Louriz et al., 2009).

The present study showed that respiratory rate was significantly higher in non-survivors compared to survivors. Comparable results were obtained by El-Ebiary et al. (2015). The increase in respiratory rate could be a compensatory response to metabolic acidosis which is the most common type of acid base disturbance in AlP poisoned patients (Jaiswal et al., 2009).

The ECG changes were significantly registered in non- survivors when compared to survivors. Parallel results were obtained by Shadnia et al. (2009) and El-Sarnagawy (2017). Sinus tachycardia was the most common change among survivors and nonsurvivors while all other changes were more common among non-survivors than survivors. Similar results were reported by El-Sarnagawy (2017). The ECG abnormalities induced by AlP poisoning could be attributed to cardio toxic effect of phosphine gas. It promotes generation of reactive oxygen species leading to lipid peroxidation with focal areas of necrosis in the myocardium (Akkaoui et al., 2007). Furthermore, it leads to inhibition of mitochondrial cytochrome $\mathrm{C}$ oxidase with subsequent depletion of myocardial energy like ischemia (Singh et al., 2006). These effects leads to changes in cardiac transmembrane action potentials causing dysrhythmia, and ischemia-like effect on ECG (El-Ebiary et al., 2015).
The mean blood $\mathrm{pH}$ and $\mathrm{HCo}_{3}$ levels were significantly lower in non-survivors compared to survivors. Similar results were obtained by Mathai and Bhanu (2010) and Navabi et al. (2018). Accumulation of lactic acid resulting from AlP induced blockage of oxidative phosphorylation and poor tissue perfusion may be the cause of metabolic acidosis which is considered the most common acid-base abnormalities in acute AlP toxicity. (Agarwal et al., 2014; Berry et al., 2015).

The mean K level was significantly lower in non-survivors compared to survivors. ElSarnagawy (2017) reported alike results. Farzaneh et al. (2018) reported insignificant lowering in $\mathrm{K}$ level in non-survivors. Hypokalemia after metal phosphides toxicity may be due to vomiting. In addition, catecholamine release could be a contributing factor (Proudfoot, 2009).

The median level of creatinine and WBCs count were significantly higher in nonsurvivors compared to survivors. Masoud and Barghash (2013) reported similar results. These effects could be explained by action of phosphine gas which inhibits the cytochrome $\mathrm{C}$ oxidase activity and causes free radical damage of tissues. Organs that have high oxygen demands (the brain, heart, kidneys and liver) appear to be very sensitive to this damage (Louriz et al., 2009).

The present study reported a significant relationship between mortality and ECG changes, GCS, blood pressure, respiratory rate, $\mathrm{pH}, \mathrm{HCo}_{3}, \mathrm{~K}$, creatine level and white blood cell count based on univariate regression analysis. Navabi et al. (2018) reported a significant relationship between mortality and delay time, blood pressure, number of ingested tablets, vomiting, $\mathrm{pH}$ and $\mathrm{HCO} 3$ level.

In the current study, multivariate analysis revealed that, ECG changes and $\mathrm{pH}$ level are the only independent variables that can predict 
mortality. On the other hand, Navabi et al. (2018) reported blood pressure, $\mathrm{pH}$ level and delay time as the most important predictive variables of mortality.

Analysis of ROC curve for blood $\mathrm{pH}$ level detected a sensitivity of 71.43 (able to predict, $71.43 \%$ of cases that died) and a specificity of 97.22 with an optimal cut-off value of $\leq 7.28$. This result was slightly different from result of (Masoud and Barghash (2013)) who reported a ROC curve analysis with a sensitivity and specificity of $100 \%$ and a best cut of value of $\cdot 7.27$.

\section{Conclusion:}

The present study concluded that AlP poisoning cause high rate of mortality. The presence of ECG changes and the blood $\mathrm{pH}$ level are the only variables that could predict mortality based on the multivariate regression analysis. Analysis of ROC curve for $\mathrm{pH}$ level as a predictor of mortality revealed that at a cut off values of $\leq 7.28$ the blood $\mathrm{pH}$ level was able to predict $71.43 \%$ of cases that died.

\section{Recommendations:}

Assessment of ECG and blood $\mathrm{pH}$ level is highly recommended in cases of AlP poisoning for early prediction of mortality in these cases. Further studies on a larger scale of cases are recommended to detect other predictors of mortality.

\section{References:}

Agarwal, A.; Robo, R.; Jain, N., et al. (2014): "Oxidative stress determined through the levels of antioxidant enzymes and the effect of $\mathrm{N}$-acetylcysteine in aluminum phosphide poisoning". Indian J. Crit. Care. Med., 18: 666-671.

Akkaoui, M.; Achour, S.; Abidi, K., et al. (2007): "Reversible myocardial injury associated with aluminum phosphide poisoning". Clin. Toxicol. (Phila.), 45: 728-731.

Berry, A.; Singh, G.; Kaur, S.J., et al. (2015): "Aluminium phosphide: toxicity mechanism and credible treatments". WJPPS, 4: 2276-2293.

Bumbrah, G.S.; Krishan, K.; Kanchan, T., et al. (2012): "Phosphide poisoning: a review of literature". Forensic Sci. Int., 214: 1-6.

Dawson, B. and Trapp, R. (2001): Basic and clinical biostatistics. B. Dawson R. Trapp (Eds.), $3^{\text {rd }}$ McGrow Hill Medical Publishing Division New York, P.P. 161-218.

El-Ebiary, A.; Elgazzar, F.; Soliman, M., et al. (2015): "Predictors of Prognosis in Acute Aluminum Phosphide Poisoning". Mansoura J. Forens. Med. Clin. Toxicol., 12: 13-26.

El-Sarnagawy, G. (2017): "Predictive factors of mortality in acute aluminum phosphide poisoning: 5 years retrospective study in Tanta Poison Control Unit". Ain Shams J. Forensic Med. Clin. Toxicol., 29: 70-79.

El Naggar, A.R.M. and El Mahdy, N.M. (2011): "Zinc phosphide toxicity with a trial of tranexamic acid in its management". J. Adv. Res., 2: 149-156.

Farnaghi, F.; Talaie, H.; Pournasiri, Z., et al. (2013): "Effect of Aluminium Phosphide Poisoning on Blood Cortisol Level". Iranian J. Toxicol., 6: 746-750.

Farzaneh, E.; Ghobadi, H.; Akbarifard, M., et al. (2018): "Prognostic Factors in Acute Aluminium Phosphide Poisoning: 
A Risk-Prediction Nomogram Approach". Basic Clin. Pharmacol. Toxicol., 123: 347-355.

Guale, F.; Stair, E.; Johnson, B., et al. (1994): "Laboratory diagnosis of zinc phosphide poisoning". Vet. Hum. Toxicol., 36: 517-519.

Hassanian - Moghaddam, H.; Zamani, N.; Rahimi, M., et al. (2016): "Successful treatment of aluminium phosphide poisoning by extracorporeal membrane oxygenation". Basic \& clinical pharmacology \& toxicology, 118: 243246.

Hosseinian, A.; Pakravan, N.; Rafiei, A., et al. (2011): "Aluminum phosphide poisoning known as rice tablet: A common toxicity in North Iran". Indian J. Med. Sci., 65: 143-150.

Jaiswal, S.; Verma, R. and Tewari, N. (2009): "Aluminum phosphide poisoning: Effect of correction of severe metabolic acidosis on patient outcome". Indian J. Crit. Care Med., 13: 21-24.

Khan, M.U. (2015): "Mortality Indicators of Aluminium Phosphide Poisoning: Experience at DHQ Hospital Rawalpindi". Ann. Pak. Inst. Med. Sci, 11: 64-66.

Louriz, M.; Dendane, T.; Abidi, K., et al. (2009): "Prognostic factors of acute aluminum phosphide poisoning". Indian J. Med. Sci., 63: 227-234.

Marashi, S.M.; Arefi, M.; Behnoush, B., et al. (2011): "Could hydroxyethyl starch be a therapeutic option in management of acute aluminum phosphide toxicity?". Med. Hypotheses, 76: 596-598.

Masoud, R.A. and Barghash, S.S. (2013): "Laboratory prognostic potential for acute aluminum phosphide poisoning". AAMJ, 11: 213-218.
Mathai, A. and Bhanu, M.S. (2010): "Acute aluminium phosphide poisoning: Can we predict mortality?". Indian J. Anaesth., 54: 302-307.

Mehrpour, O.; Jafarzadeh, M. and Abdollahi, M. (2012): "A systematic review of aluminium phosphide poisoning". Arh. Hig. Rada Toksikol., 63: 61-73.

Mostafazadeh, B.; Pajoumand, A.; Farzaneh, E., et al. (2011): "Blood levels of methemoglobin in patients with aluminum phosphide poisoning and its correlation with patient's outcome". J. Med.Toxicol., 7: 40-43.

Nagy, A.-L.; Bolfa, P.; Mihaiu, M., et al. (2015): "Intentional fatal metallic phosphide poisoning in a dog-a case report". BMC Vet. Res., 11: 158.

Navabi, S.M.; Navabi, J.; Aghaei, A., et al. (2018): "Mortality from aluminum phosphide poisoning in Kermanshah Province, Iran: characteristics and predictive factors". Epidemiol. Health, 40: 1-6.

Prashar, A. and Ramesh, M. (2018): "Assessment of pattern and outcomes of pesticides poisoning in a tertiary care hospital". Trop. Med. Int. Health, 23: 1401-1407.

Proudfoot, A.T. (2009): "Aluminium and zinc phosphide poisoning". Clin. Toxicol. (Phila.), 47: 89-100.

Shadnia, S.; Sasanian, G.; Allami, P., et al. (2009): "A retrospective 7-years study of aluminum phosphide poisoning in Tehran: opportunities for prevention". Hum. Exp. Toxicol., 28: 209-213.

Singh, S.; Bhalla, A.; Verma, S.K., et al. (2006): "Cytochrome-C oxidase inhibition in 26 aluminum phosphide 
poisoned patients". Clin. Toxicol. (Phila.), 44: 155-158.

Singh, Y.; Joshi, S.C.; Satyawali, V., et al. (2014): "Acute aluminium phosphide poisoning, what is new?". Egypt. J. Intern. Med., 26: 99-103.

Soltaninejad, K.; Nelson, L.S.; Bahreini, S.A., et al. (2012): "Fatal aluminum phosphide poisoning in Tehran-Iran from 2007 to 2010". Indian J. Med. Sci., 66: 66-70.
Sulaj, Z.; Drishti, A.; Çeko, I., et al. (2015): "Fatal aluminum phosphide poisonings in Tirana (Albania), 2009-2013". Daru, 23: 8.

Tripathi, S. and Pandey, S. (2007): "The effect of aluminium phosphide on the human brain: a histological study". Med. Sci. Law, 47: 141-146.

Vijayanath, V.; Anitha, M.; Raju, G., et al. (2011): "Forensic view on aluminium phosphide poisoning". J. Indian Acad. Forensic Med., 33: 289-291. 


\section{دور البيانات السريرية والفحوصات المختبرية وتغيرات رسم القلب في التنبؤ بالوفيات

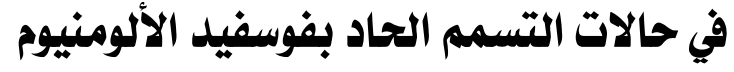

\section{أميرة أمين وهدان و هبة كامل خليفة}

قسم الطب الثرعي والسموم الاكلينيكية، كلية الطب، جامعة طنطا

فوسفيد الالومنيوم واحد من المبيدات الحشرية التي تستخدم على نطاق واسع في التبخير في مصر. تتوفر بيانـات محدودة عن المنبئـات المتعلقة بالوفيـات في المرضـي المسممين بفوسفيد الالومنيوم. لذلك، كان

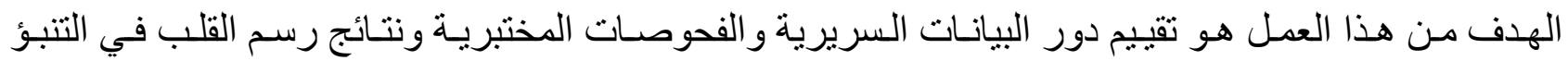

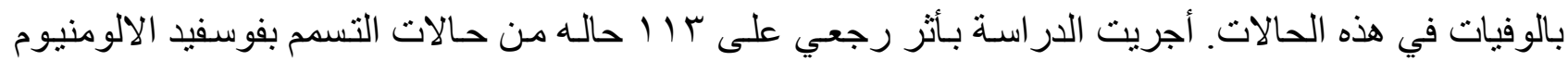

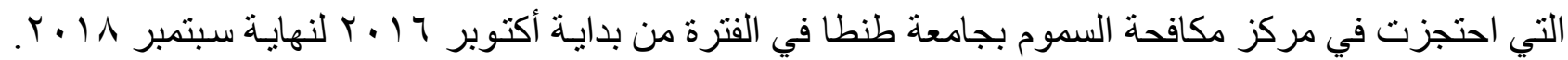

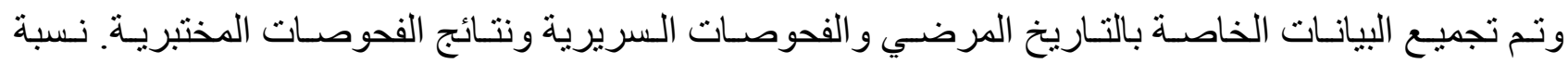

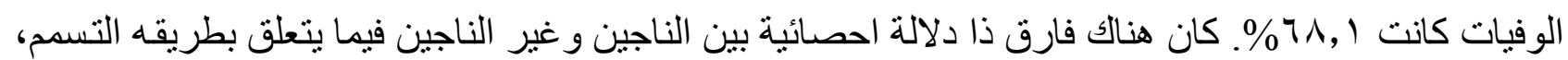

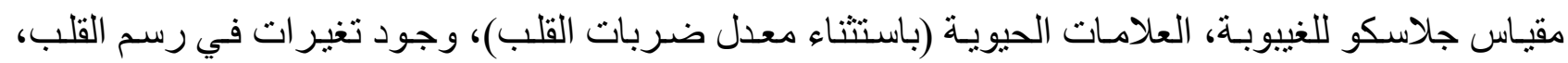
مستوى حامضية الدم، مستوى بيكربونـات الصوديوم، مستوى البوتاسيوم، مستوى الكريـاتين و عدد كر ات الدم البيضاء. وكثف الانحدار اللوجستي لتحليل متعدد المتغير ات ان تغييرات رسم القلب ومستوى حامضية الدم فقط هي المتغير ات المستقلة التي يمكنها التنبؤ بالوفيات. وقد وجد تحليل منحني (ROC) لمستوى حامضية الدمام

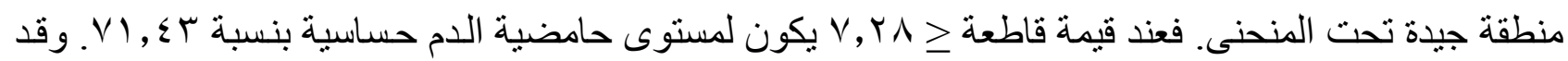
استتتج ان حالات التسمح بفوسفيد الالومنيوم تتسبب في معدل وفيات مرتفع. ويمكن التنبؤ بالوفيات من خـلال

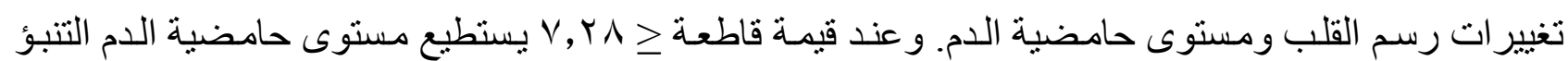
بالوفيات. لذا ينصح بتقييم رسم القلب ومستولى حامضية الدم في حالات التسمم بفوسفيد الالومنيوم للتنبؤ المبكر بالو فيات. 